\title{
GENETIC VARIATION AND OUTCROSSING RATES OF THE ENDANGERED TROPICAL SPECIES DIPTEROCARPUS DYERI
}

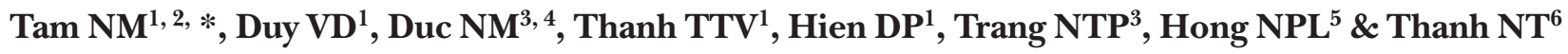 \\ ${ }^{1}$ Department of Experimental Taxonomy and Genetic Diversity, Vietnam National Museum of Nature, Vietnam Academy \\ of Science and Technology, 18 Hoang Quoc Viet, Cau Giay, Hanoi 100000, Vietnam \\ ${ }^{2}$ Graduate University of Science and Technology, Vietnam Academy of Science and Technology, 18 Hoang Quoc Viet, Cau \\ Giay, Hanoi 100000, Vietnam \\ ${ }^{3}$ Department of Molecular Systematics and Genetic Conservation, Institute of Ecology and Biological Resources, Vietnam \\ Academy of Science and Technology, 18 Hoang Quoc Viet, Cau Giay, Hanoi 100000, Vietnam \\ ${ }^{4}$ Center for Nutraceutical and Pharmaceutical Materials, Myongji University, Yongin, Gyeonggi-do 17058, South Korea \\ ${ }^{5}$ Hanoi Open University, Nguyen Trai, Thanh Xuan, Hanoi 100000 Vietnam \\ ${ }^{6}$ Hanoi University of Science, Nguyen Trai, Thanh Xuan, Hanoi 100000, Vietnam
}

*nmtam@vnmn.vast.vn

Submitted November 2018, accepted January 2019

\begin{abstract}
Dipterocarpus dyeri is an endangered species in lowland tropical forests of Vietnam because of habitat fragmentation and over-exploitation of this species. It plays an important economic and ecological role in Vietnam. Due to the importance and lack of information on its genetic diversity and mating system, we investigated genetic parameters in adults and juveniles of this species in two natural populations about 10 $\mathrm{km}$ apart. Eight polymorphic microsatellite loci were analysed and showed high genetic diversity in adults $\left(\mathrm{H}_{\mathrm{O}}=0.475-0.563, \mathrm{H}_{\mathrm{E}}=0.551-0.649\right)$ and juveniles $\left(\mathrm{H}_{\mathrm{O}}=0.47-0.513, \mathrm{H}_{\mathrm{E}}=0.576-0.685\right)$ in both populations. Results revealed differences of genetic diversity between two adult $\left(\mathrm{F}_{\mathrm{ST}}=0.123\right)$ and two juvenile populations $\left(\mathrm{F}_{\mathrm{ST}}=0.188\right)$. However, the differences were negligible and indicated that the fragmented habitat had negligible effect on genetic diversity. Gene flow or gene migration between two populations in adults or juveniles remained $\left(\mathrm{N}_{\mathrm{m}}>1\right)$, although this value reduced slightly in the latter. Analysis of the mating system indicated high outcrossing rate of D. dyeri $\left(\mathrm{t}_{\mathrm{m}}=0.8\right)$. Biparental mating $\left(\mathrm{t}_{\mathrm{m}}-\mathrm{t}_{\mathrm{s}}\right)$ was relatively high $(0.19-0.25)$ and suggested high tendency of mating system between relatives. Genetic conservation should derive from correlated outcrossing.
\end{abstract}

Keywords: Genetic diversity, fragmentation, genetic conservation, mating system, microsatellites markers

\section{INTRODUCTION}

Habitat fragmentation into small patches due to anthropogenic activities such as clearance for agricultural purposes and disturbance by selective logging are great threats to species and species groups (Lowe et al. 2005). Fragmentation not only decreases the area for population habitat but also isolates the population by larger distances. Thus, such patches can sustain small and isolated populations. The individuals in these populations increase in vulnerability to stochastic processes (Barrett \& Kohn 1991). Small and isolated populations often face increased inbreeding depression and reduced genetic variation, and lead to reduced fitness and increased susceptibility to demographic and environmental stochasticity (Bijlsma et al. 2000).
Tropical species are predominantly outcrossed via gene flow within and among populations and maintain high levels of genetic diversity (Eduardo 2008). Dispersal of pollen grains plays an important role in gene flow of plants and connectivity among populations (Hamrick 2004). Threatened trees in tropical forests with low rate of natural regeneration are related to seed quality, seedling predation and climatic conditions (Villagra et al. 2009).

Dipterocarpus dyeri, a semi-deciduous tree, is distributed in Myanmar, Thailand, Cambodia and Vietnam. In Vietnam, it is found in some provinces of Dong Nam Bo and Tay Nguyen, as well as Phu Quoc islands (Nghia 2005). The species grows as an emergent trees in lowland tropical forests 
along streams and in valleys at low elevations up to $500 \mathrm{~m}$. Dipterocarpus dyeri can reach up to $35 \mathrm{~m}$ in height and $120 \mathrm{~cm}$ in diameter. Flower is large and scented. The flowers appear every year between March and April. Fruits mature during 3 months after the flowering. The fruit consists of a single-seeded nut with wings developed from the calyx. Seeds are dispersed by wind and water flow. It is an important timber tree and plays a dominant role in the ecology and the economic value of moist evergreen forests in Vietnam. Its wood is used for construction purposes such as houses, furniture and boats. Resinous oil is used in paints and varnishes (Nghia 2005). Habitat loss, fragmentation and over-exploitation are the most important consequences that threaten this species. Dipterocarpus dyeri is listed as critically endangered on the IUCN Red List Categories (Phan et al. 2017) and Vietnam Red Data Book (Anonymous 2007).

In order to improve the conservation of this species, information on its ecology and genetic variation within and among populations is required. The evolutionary potential of the species in nature depends on its level of genetic variation and differentiation. Gene flow within and among populations can affect genetic differentiation and the evolution of population adaptations (Lenormand 2002). Studies of threatened species can improve the understanding of genetic diversity and the mating rates of mother trees within populations to establish efficient strategies for species conservation and management.

Microsatellite markers, i.e. simple sequence repeats (SSRs) are considered as powerful tools for analysing gene flow, genetic structure and mating systems (Takeuchi et al. 2004, Pandey \& Geburek 2009). They are codominant, multiallelic markers and widely distributed throughout genomes. These markers have been widely used in studies of genetic diversity within and among dipterocarp populations ( $\mathrm{Ng}$ et al. 2004, Pandey \& Geburek 2009, Rachmat et al. 2012, Muhammad et al. 2016). In previous studies, five microsatellite markers have been used for many Dipterocarpaceae species (Ujino et al. 1998). Dipterocarpaceae species are bisexual and are insect-pollinated (Bawa 1998) Some studies indicated high outcrossing rates such as in Shorea curtisii (Obayashi et al. 2002) and Shorea leprosula (Fukue et al. 2007). The main purpose of this research was to investigate genetic diversity and the mating system parameters of $D$. dyeri in two secondary forests, La Nga and Xom Moi, and to support the breeding programme in the ex-situ conservation. The two protected areas were mainly fragmented by Tri An artificial lake in the late 1980s and early 1990s. Therefore, the aims of this present work were to (1) investigate the genetic diversity within adults of $D$. dyeri and the juveniles in the two protected areas, (2) estimate the outcrossing rates, mating between relatives, paternity correction rates in mother trees in disturbed habitats, and (3) determine the maternal trees to collect seeds for ex-situ conservation.

\section{MATERIALS AND METHODS}

\section{Plant materials and DNA isolation}

Samples were collected from two $D$. dyeri natural populations, namely, Xom Moi secondary forest $\left(11^{\circ} 07^{\prime} \mathrm{N}, 107^{\circ} 09^{\prime} \mathrm{E}\right)$ and La Nga secondary forest $\left(11^{\circ} 06^{\prime} \mathrm{N}, 107^{\circ} 25^{\prime} \mathrm{E}\right)$ about $10 \mathrm{~km}$ from Xom Moi in Dong Nam Bo region of Vietnam. The adult trees for the study were randomly sampled in the populations. Two consecutive adults were sampled at least $100 \mathrm{~m}$ apart from each other in each population. During the fruiting season (April-May), mature fruits were collected for seeds, which were propagated at Bien Hoa nursery. The plantlets were grown in the nursery. Twenty mother trees (adults) and 185 of their offspring (juveniles) were used for the study. In addition, 81 non-related adults, also from Xom Moi and La Nga, were used for the analysis of genetic diversity. DNA samples of adults were obtained from inner bark tissue, whereas those of juveniles, from leaf tissue. In the field, samples were placed into plastic bags with silica gel and taken to Laboratory of Molecular Biology, Vietnam National Museum of Nature, where they were stored at $-30{ }^{\circ} \mathrm{C}$ until DNA extraction was performed. The two populations (Xom Moi and La Nga) are located in secondary forests, where their vegetation is greatly affected by anthropogenic activities such as clearance for cultivation and logging, and fragmented by the artificial lake of Tri An. In addition, they were isolated by the clearance of $D$. dyeri habitat for cultivation.

Genomic DNA was extracted using the adapted cetyltrimethyl ammonium bromide (CTAB) method described by Doyle and Doyle 
(1990). The total amount of DNA was determined uisng fluorimetry and it was diluted to a final concentration $10 \mathrm{ng} \mathrm{L}^{-1}$ for microsatellite analysis.

\section{Microsatellite analysis}

DNA amplifications were performed by polymerase chain reaction (PCR) using 19 microsatellite pairs developed for dipterocarp species (Terauchi 1994, Ujino et al. 1998, Isagi et al. 2002). The eight nuclear microsatellite markers (SSRs) were chosen on the basis of polymorphism reproduced in preliminary tests (Table 1$)$. The total reaction volume $(25 \mu \mathrm{L})$ contained $1 \times$ PCR buffer $(10 \mathrm{mM}$ TrisHCl, $50 \mathrm{mM} \mathrm{KCl}, \mathrm{pH} 8.4), 0.2 \mathrm{mM}$ of each dNTP, $2.5 \mathrm{mM} \mathrm{MgCl}_{2}, 10 \mathrm{ng}$ genomic DNA, $1.25 \mathrm{U}$ Taq DNA polymerase, and 10 pmol of each primer. The amplifications were performed in the GeneAmp PCR System 9700 under the following conditions: a denaturing step at $94^{\circ} \mathrm{C}$ for $3 \mathrm{~min}, 40$ cycles of $94^{\circ} \mathrm{C}$ for $1 \mathrm{~min}, 54-56^{\circ} \mathrm{C}$ for $30 \mathrm{~s}$ for each primer pair and $72^{\circ} \mathrm{C}$ for $1 \mathrm{~min}$, followed by a final extension step at $72{ }^{\circ} \mathrm{C}$ for $10 \mathrm{~min}$ to complete the extension of any remaining products before holding the samples at $4{ }^{\circ} \mathrm{C}$ until further analysis. The amplification products were separated using a DNA electrophoresis system in $7.5 \%(\mathrm{w} / \mathrm{v})$ polyacrylamide gels in TAE buffer and then visualised by nucleic acid gel stain. Alleles were sized using gel-analyzer software with 50 bp DNA ladder.

\section{Data analysis}

Variables for genetic diversity within populations, including the number of alleles per locus $\left(\mathrm{N}_{\mathrm{A}}\right)$, number of effective alleles $\left(\mathrm{N}_{\mathrm{E}}\right)$, number of private alleles $\left(\mathrm{N}_{\mathrm{P}}\right)$, Shannon's information index $(\mathrm{I})$, and the observed $\left(\mathrm{H}_{\mathrm{O}}\right)$ and expected $\left(\mathrm{H}_{\mathrm{E}}\right)$ heterozygosities, were calculated using the GenALEx 6.5 software. Genetic variation among populations was also calculated using FSTAT v2.9.3.2, including intrapopulation inbreeding coefficients $\left(\mathrm{F}_{\mathrm{IS}}\right)$ and the interpopulation genetic differentiation coefficient $\left(\mathrm{F}_{\mathrm{ST}}\right)$. Tests of deviation from the Hardy-Weinberg equilibrium at each locus and the linkage disequilibrium between the pair of loci in each population were performed by GENEPOP v4.6. Significant values were adjusted by Bonferroni correction $(95 \%, \alpha=0.05)$. Analyses were separately implemented for adults and juveniles from each population. Significance testing for variance components in the analysis of molecular variance was implemented on the basis of 10,000 permutations using Arlequin 3.1. The gene flow for adults and juveniles between La Nga and Xom Moi was determined using $\mathrm{F}_{\mathrm{ST}}$ value: $\mathrm{N}_{\mathrm{m}}=\left(1 / \mathrm{F}_{\mathrm{ST}}-1\right) / 4$.

Table 1 Characteristics of polymorphic microsatellite loci for Dipterocarpus dyeri

\begin{tabular}{|c|c|c|c|c|c|c|}
\hline Locus & Primer sequences (5'-3') & Repeat motif & $\begin{array}{l}\mathrm{Tm} \\
\left({ }^{\circ} \mathrm{C}\right)\end{array}$ & $\begin{array}{c}\text { Allele } \\
\text { size (bp) }\end{array}$ & $\begin{array}{l}\text { Number } \\
\text { of alleles }\end{array}$ & Sources \\
\hline D1 & $\begin{array}{l}\text { F: CTTCCCTAAATTCCCCAATGTT } \\
\text { R: TAATGGTGTGTGTACCAGGCAT }\end{array}$ & $(\mathrm{AG})_{15}$ & 55 & $193-211$ & 3 & $\begin{array}{l}\text { Isagi et al. } \\
\quad 2002\end{array}$ \\
\hline $\mathrm{D} 2$ & $\begin{array}{l}\text { F: AGTTTTATACATCACCGCCAA } \\
\text { R: GAAGCCCCTAAGAATTAACCTGA }\end{array}$ & $(\mathrm{GA})_{17}$ & 56 & $114-142$ & 5 & $\begin{array}{l}\text { Isagi et al. } \\
\quad 2002\end{array}$ \\
\hline D3 & $\begin{array}{l}\text { F: ACAATGAAACTTGACCACCCAT } \\
\text { R: CAAAAGGACATACCAGCCTAGC }\end{array}$ & $(\mathrm{GA})_{24}$ & 56 & $224-256$ & 5 & $\begin{array}{l}\text { Isagi et al. } \\
\quad 2002\end{array}$ \\
\hline $\mathrm{D} 4$ & $\begin{array}{l}\text { F: TAGGGCATATTGCTTTCTCATC } \\
\text { R: CTTATTGCAGTCATCAAGGGAA }\end{array}$ & $(\mathrm{AG})_{15}$ & 55 & $214-256$ & 6 & $\begin{array}{l}\text { Isagi et al. } \\
\quad 2002\end{array}$ \\
\hline D5 & $\begin{array}{l}\text { F: CAGGAGGGGAATATGGAAAA } \\
\text { R: AAGTCGTCATCTTTGGATTGC }\end{array}$ & $(\mathrm{AC})_{9}$ & 54 & $120-150$ & 5 & $\begin{array}{l}\text { Isagi et al. } \\
\quad 2002\end{array}$ \\
\hline D6 & $\begin{array}{l}\text { F: ATGCTTACCACCAATGTGAATG } \\
\text { R: CTCGCAGCAGAACAACTTTCTA }\end{array}$ & $(\mathrm{GA})_{6}$ & 55 & $170-270$ & 7 & $\begin{array}{l}\text { Terauchi } \\
1994\end{array}$ \\
\hline D7 & $\begin{array}{l}\text { F: TGGCAAACAAGCTACTGTTCAT } \\
\text { R: CATGGGTTTAGCAACCTACACA }\end{array}$ & $(\mathrm{TA})_{8}$ & 56 & $258-286$ & 4 & $\begin{array}{l}\text { Isagi et al. } \\
2002\end{array}$ \\
\hline D8 & $\begin{array}{l}\text { F: ATGTC CATGT TTGAG TG } \\
\text { R: CATGG ACATA AGTGG AG }\end{array}$ & $\begin{array}{c}(\mathrm{CT})_{8} \mathrm{CA}(\mathrm{CT})_{5} \\
\mathrm{CACCC}(\mathrm{CT} \\
\left.\mathrm{CA})_{3} \mathrm{CTCA}\right)_{10}\end{array}$ & 55 & $170-230$ & 5 & $\begin{array}{l}\text { Ujino et al. } \\
\quad 1998\end{array}$ \\
\hline
\end{tabular}


Mating system parameters were estimated using the program MLTR based on the mixed mating model (Ritland \& Jain 1981). This model assumed (1) each mating event was due to random outcrossing or self-fertilisation, (2) the probability of outcrossing was independent of maternal genotype, (3) the pollen allele frequencies were homogeneous for all maternal trees, (4) the selection did not occur between fertilisation and the time of progeny arrays, and (5) alleles at different loci were independently segregated. The multilocus outcrossing rate $\left(\mathrm{t}_{\mathrm{m}}\right)$, single locus outcrossing rate $\left(\mathrm{t}_{\mathrm{s}}\right)$ and the correlated paternity $\left(r_{p}\right)$ were analysed using MLTR. Neighborhood $=1 / r_{p}$ indicated the effective number of pollen donors contributing to each mother tree (Ritland 1989). Standard errors (SE) of parameters were generated by 1000 re-sampling bootstraps. In order to determine whether the values were significantly lower than one with $t_{m}$ and $t_{s}$ or greater than zero with $F_{m}$, $\mathrm{t}_{\mathrm{m}}-\mathrm{t}_{\mathrm{s}}, \mathrm{r}_{\mathrm{p}}$ and mean $\pm 1.96 \mathrm{SE}$ were considered.

\section{RESULTS}

\section{Genetic diversity within adults and juveniles}

The values of genetic diversity in adult trees and juveniles of D. dyeri in La Nga and Xom Moi are presented in Table 2. All SSR loci were highly polymorphic for adults and juveniles in the two populations. The number of alleles per locus ranged from 3 to 5 in adult trees and 3 to 6 in juveniles. The total number of alleles of juveniles was higher than that of adults in both populations. Average number of alleles $\left(\mathrm{N}_{\mathrm{A}}\right)$ for adults was 3.9 and 3.7 in Xom Moi and La Nga respectively, whereas the $\mathrm{N}_{\mathrm{A}}$ values for juveniles were 4.4 and 4.5 in the two populations respectively. Similarly, the average effective

Table 2 Genetic diversity and fixation index of Dipterocarpus dyeri adult and juvenile trees

\begin{tabular}{|c|c|c|c|c|c|c|c|c|c|c|c|c|}
\hline \multirow{2}{*}{ Locus } & \multicolumn{6}{|c|}{ Adults $(\mathrm{N}=55)$} & \multicolumn{6}{|c|}{ Juveniles $(\mathrm{N}=85)$} \\
\hline & $\mathrm{N}_{\mathrm{A}}$ & $\mathrm{N}_{\mathrm{E}}$ & I & $\mathrm{H}_{\mathrm{O}}$ & $\mathrm{H}_{\mathrm{E}}$ & $\mathrm{F}_{\text {IS }}$ & $\mathrm{N}_{\mathrm{A}}$ & $\mathrm{N}_{\mathrm{E}}$ & I & $\mathrm{H}_{\mathrm{O}}$ & $\mathrm{H}_{\mathrm{E}}$ & $\mathrm{F}_{\text {IS }}$ \\
\hline \multicolumn{13}{|c|}{ Xom Moi population } \\
\hline D1 & 5 & 3.1 & 1.31 & 0.545 & 0.681 & 0.199 & 5 & 1.7 & 0.78 & 0.361 & 0.412 & 0.122 \\
\hline D2 & 5 & 3.6 & 1.37 & 0.564 & 0.720 & 0.217 & 5 & 1.5 & 0.98 & 0.398 & 0.488 & 0.184 \\
\hline D3 & 4 & 1.9 & 0.9 & 0.473 & 0.495 & 0.045 & 5 & 3.8 & 1.47 & 0.627 & 0.740 & $0.153 *$ \\
\hline D4 & 3 & 1.6 & 0.66 & 0.327 & 0.362 & 0.097 & 3 & 1.3 & 0.52 & 0.181 & 0.258 & 0.301 \\
\hline D5 & 3 & 2.2 & 0.99 & 0.545 & 0.546 & 0.001 & 5 & 3.6 & 1.43 & 0.747 & 0.726 & -0.029 \\
\hline D6 & 4 & 1.6 & 0.77 & 0.327 & 0.393 & $0.168^{*}$ & 4 & 2.6 & 1.13 & 0.434 & 0.649 & $0.332 *$ \\
\hline D7 & 4 & 2.6 & 1.1 & 0.509 & 0.615 & 0.173 & 4 & 2.7 & 1.1 & 0.313 & 0.629 & $0.502 *$ \\
\hline D8 & 3 & 2.5 & 0.97 & 0.509 & 0.595 & 0.145 & 4 & 3.2 & 1.27 & 0.699 & 0.695 & -0.006 \\
\hline Mean & 3.9 & 2.4 & 0.99 & 0.475 & 0.551 & $0.131 *$ & 4.4 & 2.6 & 1.08 & 0.47 & 0.576 & $0.198 *$ \\
\hline \multirow{2}{*}{ Locus } & \multicolumn{6}{|c|}{ Adults $(\mathrm{N}=46)$} & \multicolumn{6}{|c|}{ Juveniles $(\mathrm{N}=100)$} \\
\hline & $\mathrm{N}_{\mathrm{A}}$ & $\mathrm{N}_{\mathrm{E}}$ & I & $\mathrm{H}_{\mathrm{O}}$ & $\mathrm{H}_{\mathrm{E}}$ & $\mathrm{F}_{\text {IS }}$ & $\mathrm{N}_{\mathrm{A}}$ & $\mathrm{N}_{\mathrm{E}}$ & I & $\mathrm{H}_{\mathrm{O}}$ & $\mathrm{H}_{\mathrm{E}}$ & $\mathrm{F}_{\text {IS }}$ \\
\hline
\end{tabular}

La Nga population

\begin{tabular}{lllllllllllll} 
D1 & 4 & 3.1 & 1.17 & 0.565 & 0.677 & 0.166 & 4 & 3.2 & 1.31 & 0.47 & 0.714 & $0.342^{*}$ \\
D2 & 5 & 3.6 & 1.41 & 0.609 & 0.721 & 0.156 & 5 & 3.5 & 1.33 & 0.43 & 0.707 & 0.392 \\
D3 & 4 & 2.4 & 1.06 & 0.522 & 0.584 & 0.106 & 6 & 4.9 & 1.67 & 0.69 & 0.798 & $0.135^{*}$ \\
D4 & 3 & 2.4 & 0.98 & 0.500 & 0.586 & 0.147 & 3 & 2.9 & 1.09 & 0.45 & 0.663 & $0.322^{*}$ \\
D5 & 3 & 2.4 & 0.95 & 0.543 & 0.585 & 0.071 & 5 & 2.1 & 0.81 & 0.47 & 0.526 & 0.107 \\
D6 & 4 & 3.1 & 1.24 & 0.630 & 0.679 & 0.071 & 4 & 3.1 & 1.34 & 0.51 & 0.675 & $0.245^{*}$ \\
D7 & 4 & 3.7 & 1.35 & 0.587 & 0.731 & 0.197 & 5 & 3.9 & 1.48 & 0.52 & 0.747 & $0.304^{*}$ \\
D8 & 3 & 2.7 & 1.03 & 0.543 & 0.626 & $0.132^{*}$ & 4 & 1.9 & 1.19 & 0.56 & 0.651 & $0.139^{*}$ \\
\hline Mean & 3.7 & 2.9 & 1.15 & 0.563 & 0.649 & $0.132^{*}$ & 4.5 & 3.2 & 1.28 & 0.513 & 0.685 & $0.248^{*}$ \\
\hline
\end{tabular}

$\mathrm{N}_{\mathrm{A}}$ = number of alleles, $\mathrm{N}_{\mathrm{E}}$ = effective number of alleles, $\mathrm{I}=$ Shannon information index, $\mathrm{H}_{\mathrm{O}}=$ observed heterozygosity, $\mathrm{H}_{\mathrm{E}}=$ expected heterozygosity, $\mathrm{F}_{\mathrm{IS}}=$ inbreeding coefficient with $* \mathrm{p}<0.05$ 
number of alleles $\left(\mathrm{N}_{\mathrm{E}}\right)$ for juveniles was higher than for adults in the two populations. The $\mathrm{N}_{\mathrm{E}}$ values for adults were 2.4 in Xom Moi and 2.9 in La Nga. For juveniles, $\mathrm{N}_{\mathrm{E}}$ values were 2.6 and 3.2 in the two populations respectively. The average Shannon information indices in both populations were slightly lower in adult trees than in juvenile trees (adult 0.99 in Xom Moi and 1.15 in La Nga vs. juvenile 1.08 and 1.28 respectively). Although the observed heterozygosity $\left(\mathrm{H}_{\mathrm{O}}=\right.$ 0.475 ) in adult trees was similar to juvenile trees, the expected heterozygosity was slightly higher in juvenile trees $\left(\mathrm{H}_{\mathrm{E}}=0.576\right)$ than in adult trees $\left(\mathrm{H}_{\mathrm{E}}=0.551\right)$ in Xom Moi. The observed heterozygosity for La Nga was slightly higher in adults $\left(\mathrm{H}_{\mathrm{O}}=0.563\right)$ than in juveniles $(0.513)$, whereas $\mathrm{H}_{\mathrm{E}}$ was higher in juveniles $(0.685)$ than in adults $(0.649)$. The average number of private alleles was found for juveniles in Xom Moi $\left(\mathrm{N}_{\mathrm{P}}=0.4\right)$ and La Nga $\left(\mathrm{N}_{\mathrm{P}}=0.62\right)$, while this value was not found in adults in both populations. The allelic patterns across adults and juveniles in Xom Moi and La Nga are presented in Figure 1. HardyWeinberg equilibrium tests showed that the values of inbreeding coefficient had significant deviations $(\mathrm{p}<0.05)$ at one locus in adults of both populations, three loci for juveniles in Xom Moi and the most loci for juveniles in La Nga, after the Bonferroni correction. Linkage disequilibrium tests showed significant deviations at three and four pairs of loci for juveniles in Xom Moi and La Nga respectively $(\mathrm{p}<0.05)$. The fixation index $\left(\mathrm{F}_{\mathrm{IS}}\right)$ was negative and had no significant deviation at two loci, D5 and D8, for juveniles in Xom Moi $(p>0.05)$. The mean $F_{I S}$ values for adults and juveniles in both populations were positive and significant $(\mathrm{p}<0.05)$ and indicated a departure from Hardy-Weinberg equilibrium with an excess of homozygotes and inbreeding.
However, $\mathrm{F}_{\text {IS }}$ values differed between adults and juveniles in two populations. The $\mathrm{F}_{\mathrm{IS}}$ in juveniles was higher than that of adults and suggested a remarkable decrease in heterozygotes within juvenile trees.

The analysis of molecular variance revealed genetic variation among populations and within populations for adult and juvenile trees. Total variation was $87.71 \%$ within the adult populations and $81.25 \%$ for the juvenile populations (Table $3)$. The population pairwise differentiations were significant for both adults and juveniles $(p<0.001)$. The juvenile population differentiation $\left(\mathrm{F}_{\mathrm{ST}}\right)$ was 0.188 and gene flow $\left(\mathrm{N}_{\mathrm{m}}\right)$ was 1.08. For adult trees, $\mathrm{F}_{\mathrm{ST}}$ value was 0.123 and $\mathrm{N}_{\mathrm{m}}$ was 1.78 . The relative high differentiation suggested a decrease of gene exchange between juvenile populations (results not shown).

\section{Mating system parameters}

Microsatellite analysis indicated that $D$. dyeri had relatively high outcrossing. The multilocus outcrossing $\left(\mathrm{t}_{\mathrm{m}}\right)$ and single-locus $\left(\mathrm{t}_{\mathrm{s}}\right)$ rates for each half-sib family (mother tree) and populations in Xom Moi and La Nga are presented in Table 4. The individual multilocus outcrossing rates per mother tree were high in all the mother trees, except for mother tree 9 with $\mathrm{t}_{\mathrm{m}}=0.355, \mathrm{t}_{\mathrm{s}}=0.168$, and mother tree $1, \mathrm{t}_{\mathrm{s}}=0.23$ in La Nga and mother tree 7 with $\mathrm{t}_{\mathrm{s}}=0.319$ and mother tree $1, \mathrm{t}_{\mathrm{s}}=0.435$ in the Xom Moi population. Significant differences were found for the multilocus outcrossing rates at three mother trees (mother trees 1, 3 and 9) in the La Nga population and two mother trees (6 and 7) in Xom Moi. No significant difference was found for the singlelocus outcrossing

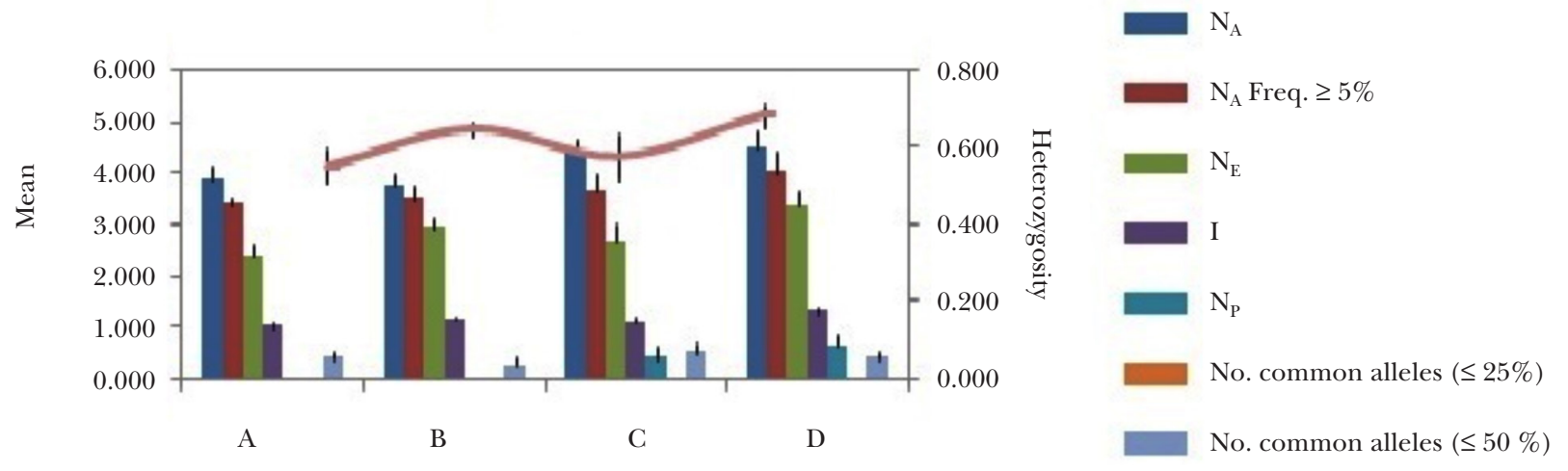

Figure 1 Allelic pattern across adults and juveniles: $\mathrm{A}=$ Xom Moi adults, $\mathrm{B}=\mathrm{La}$ Nga adults, $\mathrm{C}=\mathrm{Xom}$ Moi juveniles and $\mathrm{D}=$ La Nga juveniles; $\mathrm{N}_{\mathrm{A}}=$ no. of alleles, $\mathrm{N}_{\mathrm{E}}=$ effective number of alleles, $\mathrm{N}_{\mathrm{P}}=$ no. private alleles, I = Shannon's information index 
Table 3 Analysis of molecular variance of Dipterocarpus dyeri inveniles and adults

\begin{tabular}{|c|c|c|c|c|c|}
\hline Source of variation & $\mathrm{df}$ & Sum of squares & Variance components & Total variation $(\%)$ & $\mathrm{p}$ value \\
\hline \multicolumn{6}{|l|}{ Juveniles } \\
\hline $\begin{array}{l}\text { Between two } \\
\text { populations of Xom } \\
\text { Moi and La Nga }\end{array}$ & 1 & 110.928 & 0.589 & 18.75 & $<0.0001$ \\
\hline Within populations & 368 & 940.231 & 2.555 & 81.25 & $<0.0001$ \\
\hline Total & 369 & 1051.159 & 3.145 & & \\
\hline \multicolumn{6}{|l|}{ Adults } \\
\hline $\begin{array}{l}\text { Between two } \\
\text { populations of Xom } \\
\text { Moi and La Nga }\end{array}$ & 1 & 36.444 & 0.339 & 12.29 & $<0.0001$ \\
\hline Within populations & 200 & 484.754 & 2.424 & 87.71 & $<0.0001$ \\
\hline Total & 201 & 521.198 & 2.763 & & \\
\hline
\end{tabular}

$\mathrm{df}=$ degree of freedom

Table 4 Mating system parameters of $D$. dyeri from two populations based on microsatellite analysis

\begin{tabular}{|c|c|c|c|c|c|c|c|}
\hline \multicolumn{5}{|c|}{ Xom Moi population } & \multicolumn{3}{|c|}{ La Nga population } \\
\hline \multicolumn{8}{|c|}{ Mating system parameters at mother tree level } \\
\hline Mother tree & $\begin{array}{l}\text { Number of } \\
\text { progenies } \\
\text { analysed }\end{array}$ & \multicolumn{2}{|c|}{$\begin{array}{l}\text { Multilocus } \\
\text { outcrossing } \\
\text { rate }\left(\mathrm{t}_{\mathrm{m}}\right)(\mathrm{SE})\end{array}$} & $\begin{array}{l}\text { Single-locus } \\
\text { outcrossing rate } \\
\left(\mathrm{t}_{\mathrm{s}}\right)(\mathrm{SE})\end{array}$ & $\begin{array}{l}\text { Number of } \\
\text { progenies } \\
\text { analysed }\end{array}$ & $\begin{array}{l}\text { Multilocus } \\
\text { outcrossing rate } \\
\left(\mathrm{t}_{\mathrm{m}}\right)(\mathrm{SE})\end{array}$ & $\begin{array}{l}\text { Single-locus } \\
\text { outcrossing rate } \\
\left(\mathrm{t}_{\mathrm{s}}\right)(\mathrm{SE})\end{array}$ \\
\hline Mother tree 1 & 9 & \multicolumn{2}{|c|}{$0.937(0.036)$} & $0.435(0.125)$ & 13 & $0.753(0.095)$ & $0.23 \quad(0.08)$ \\
\hline Mother tree 2 & 7 & \multicolumn{2}{|c|}{$1.0(0.001)$} & $0.712(0.134)$ & 9 & $1.0(0.001)$ & $0.834(0.096)$ \\
\hline Mother tree 3 & 7 & \multicolumn{2}{|c|}{$0.981(0.024)$} & $0.654(0.093)$ & 13 & $0.773(0.112)$ & $0.716(0.159)$ \\
\hline Mother tree 4 & 8 & \multicolumn{2}{|c|}{$1.0(0.001)$} & $0.925(0.141)$ & 8 & $0.959(0.052)$ & $0.602(0.111)$ \\
\hline Mother tree 5 & 12 & \multicolumn{2}{|c|}{$1.0(0.001)$} & $1.0(0.076)$ & 18 & $0.936(0.038)$ & $0.823(0.084)$ \\
\hline Mother tree 6 & 5 & \multicolumn{2}{|c|}{$0.815(0.029)$} & $0.619(0.108)$ & 7 & $1.0(0.001)$ & $0.587(0.075)$ \\
\hline Mother tree 7 & 7 & \multicolumn{2}{|c|}{$0.87(0.015)$} & $0.319(0.046)$ & 7 & $0.983(0.019)$ & $0.452(0.132)$ \\
\hline Mother tree 8 & 14 & \multicolumn{2}{|c|}{$0.959(0.026)$} & $0.517(0.074)$ & 10 & $1.0(0.009)$ & $0.674(0.073)$ \\
\hline Mother tree 9 & 6 & \multicolumn{2}{|c|}{$0.938(0.052)$} & $0.746(0.084)$ & 6 & $0.355(0.108)$ & $0.168(0.102)$ \\
\hline Mother tree 10 & 10 & \multicolumn{2}{|c|}{$0.999(0.001)$} & $0.606(0.105)$ & 9 & $1.0(0.001)$ & $0.84 \quad(0.108)$ \\
\hline \multicolumn{8}{|c|}{ Mating system parameters at population level ( \pm standard error) } \\
\hline \multicolumn{3}{|c|}{ Multilocus outcrossing rate $\left(\mathrm{t}_{\mathrm{m}}\right)$} & \multicolumn{2}{|c|}{$0.803(0.071)$} & \multicolumn{2}{|c|}{ Multilocus outcrossing rate $\left(\mathrm{t}_{\mathrm{m}}\right)$} & $0.802(0.055)$ \\
\hline \multicolumn{3}{|c|}{ Single-locus outcrossing rate $\left(\mathrm{t}_{\mathrm{s}}\right)$} & \multicolumn{2}{|c|}{$0.612(0.056)$} & \multicolumn{2}{|c|}{ Single locus outcrossing rate $\left(t_{s}\right)$} & $0.552(0.065)$ \\
\hline \multicolumn{3}{|c|}{ Correlation of paternity $\left(\mathrm{r}_{\mathrm{p}}\right)$} & \multicolumn{2}{|c|}{$0.412(0.057)$} & \multicolumn{2}{|c|}{ Correlation of paternity $\left(\mathrm{r}_{\mathrm{p}}\right)$} & $0.426(0.071)$ \\
\hline \multicolumn{3}{|c|}{ Neighborhood } & \multicolumn{2}{|c|}{2.427} & \multicolumn{2}{|c|}{ Neighborhood } & 2.347 \\
\hline \multicolumn{3}{|c|}{$\begin{array}{l}\text { Inbreeding coefficient of maternal } \\
\text { parents }\left(\mathrm{F}_{\mathrm{m}}\right)\end{array}$} & \multicolumn{2}{|c|}{$-0.19(0.021)$} & \multicolumn{2}{|c|}{$\begin{array}{l}\text { Inbreeding coefficient of } \\
\text { maternal parents }\left(\mathrm{F}_{\mathrm{m}}\right)\end{array}$} & $-0.2(0.018)$ \\
\hline
\end{tabular}

$\mathrm{SE}=$ Standar error

rates at three mother trees $(2,3$ and 10) in La Nga and two mother trees (4 and 5) in Xom Moi. The multilocus outcrossing rates were 0.802 for the La Nga population and 0.803 for the Xom Moi population and showed that $80.2 \%$ of the mating relative to outcrossing and $19.8 \%$ relative to self-fertilisation in La Nga, and 80.3 and $19.7 \%$ respectively in Xom Moi. The multilocus outcrossing rates differed significantly from unity for both populations $(<1)$ and indicated that biparental inbreeding contributed to the apparent selfing rate in 
populations. Both populations indicated about $20 \%$ selfing including biparental inbreeding. However, the single-locus outcrossing rates were low $\left(t_{\mathrm{s}}=0.552\right.$ and 0.612 for La Nga and Xom Moi respectively) and significantly different. The differences between the multilocus and single-locus outcrossing rates $\left(\mathrm{t}_{\mathrm{m}}-\mathrm{t}_{\mathrm{s}}\right)$ were high, $18.9 \%$ for Xom Moi and 25\% for La Nga, and they were significantly different from zero $(>0)$. Inbreeding coefficients of maternal parents were -0.2 in La Nga and -0.19 in Xom Moi, and no significant difference from zero was found, and indicated a slight excess of heterozygotes. The estimates of correlation of multilocus and single-locus paternity $\left(r_{p}=0.426\right.$ and 0.412 for La Nga and Xom Moi respectively) were significantly different from zero $(>0)$ and indicated that less than three fathers contributed to an individual mother tree.

\section{DISCUSSION}

\section{Genetic diversity}

Genetic diversity may be reduced after fragmented and disturbed habitat (Lowe et al. 2005). Habitat fragmentation has a negative effect on genetic diversity within populations and increases genetic differentiation among populations that are associated with the decreased gene flow, inbreeding and increased random genetic drift (Bijlsma et al. 2000). The obtained results indicated that genetic diversity were relatively high in adults and juveniles in both $D$. dyeri populations, Xom Moi and La Nga. Our estimates of observed and expected heterozygosity values for $D$. dyeri were 0.505 and 0.615 respectively. These were similar to the values of previous finding for some other dipterocarps using microsatellite markers, such as $S$. leprosula $\left(\mathrm{H}_{\mathrm{O}}=0.63-0.66, \mathrm{H}_{\mathrm{E}}=0.69-0.71 ; \mathrm{Ng}\right.$ et al. 2004), Shorea robusta $\left(\mathrm{H}_{\mathrm{O}}=0.68, \mathrm{H}_{\mathrm{E}}=0.68\right.$; Pandey \& Geburek 2011), and reflected the species ecology and history. The species is widely distributed and has a long life. However, our results were high compared with Parashorea malaanonan $\left(\mathrm{H}_{\mathrm{O}}=0.26, \mathrm{H}_{\mathrm{E}}=0.46\right.$; Abasolo et al. 2009), Shorea javanica $\left(\mathrm{H}_{\mathrm{O}}=0.281, \mathrm{H}_{\mathrm{E}}=0.477\right.$; Rachmat et al. 2012), Hopea odorata $\left(\mathrm{H}_{\mathrm{O}}=0.366\right.$, $\mathrm{H}_{\mathrm{E}}=0.356$; Trang et al. 2014), Dipterocarpus alatus $\left(\mathrm{H}_{\mathrm{O}}=0.209, \mathrm{H}_{\mathrm{E}}=0.239\right.$; Tam et al. 2014), and D. dyeri in the Tan Phu forest $\left(\mathrm{H}_{\mathrm{O}}=0.375\right.$, $\mathrm{H}_{\mathrm{E}}=0.427$; Nguyen et al. 2015). One of major reasons contributing to high genetic diversity of $D$. dyeri might be related to the large population size in both populations, with $>500$ mature trees per population. However, our results were estimated based on two D. dyeri fragmented populations, while the above mentioned studies considered several populations within the natural range. The high levels of genetic diversity in $D$. dyeri indicated that the genetic polymorphic levels maintained before its habitat was fragmented by the construction of the artificial lake of Tri An and the clearance of habitat for cultivation. Although observed heterozygosity was low in juveniles compared with adults, the expected heterozygosity in the former was slightly higher than that of the latter in the two populations and suggested homozygotes were reduced during the life cycle of the tree. The reduced levels of observed heterozygosity in juvenile trees within each isolated population after habitat fragmentation suggested that gene flow was reduced via restriction of dispersal of pollen grains by insects (bees) and seed dispersal by wind and water. Inbreeding values were high and significant in juveniles in both populations which suggested high endogamy. A great deficiency of heterozygotes in juvenile trees of $D$. dyeri by high inbreeding coefficients indicated that inbreeding was recurrent, possibly related to mating by selfing. The great decrease of heterozygotes might have negative impact on the survival of juveniles and contribute to their gradual loss throughout the life cycle of trees. Genetic differentiation was higher in juveniles $\left(\mathrm{F}_{\mathrm{ST}}=0.186\right)$ than in adults $(0.121)$, suggesting semi-isolation of the two adult populations. Maternal alleles appeared more than disproportionately in juveniles and contributed to higher $\mathrm{F}_{\mathrm{ST}}$ value. High levels of gene flow $\left(\mathrm{N}_{\mathrm{m}}\right.$ $>1$ ) were maintained through pollen dispersal, although the gene flow was lower in juveniles $\left(\mathrm{N}_{\mathrm{m}}\right.$ $=1.08$ ) compared with adults (1.12). Clearly, the fragmented habitat had a negligible effect on genetic diversity between the two populations.

\section{Mating system}

There were high outcrossing rates in La Nga $\left(\mathrm{t}_{\mathrm{m}}=\right.$ 0.802 ) with a relatively high value of correction of paternity $\left(r_{p}=0.426\right)$ and in Xom Moi $(0.803$ and 0.412 respectively). The mean outcrossing rate of 0.802 for the two populations, with relatively high correction of paternity might be related 
to pollen transfer among mature trees during reproduction. These results also reflect the life history traits of $D$. dyeri (living up to 100 years or more and widespread species) and efficient gene flow among populations $\left(\mathrm{N}_{\mathrm{m}}>1\right)$, and are supported by high genetic diversity. These are similar with other studies using allozyme data such as Shorea congestiflora $\left(\mathrm{t}_{\mathrm{m}}=0.87\right.$; Murawski et al. 1994), Drybalanops aromatica 0.82; Kitamura et al. 1994), Stemonoporus oblongifolius (0.84; Murawski \& Bawa 1994), and S. leprosula (0.84; Lee et al. 2000). The multilocus outcrossing rates varied from single locus outcrossing rates in two populations $\left(\mathrm{t}_{\mathrm{m}}-\mathrm{t}_{\mathrm{s}}=0.25\right.$ and 0.19 in La Nga and Xom Moi respectively) and were significant, and indicated the occurrence of biparental inbreeding that contributed to apparent selfing rates in $D$. dyeri populations. The correlation of outcrossed paternity was relatively high and significant in both populations. As much as 43 and $41 \%$ of the outcrossed progeny pairs in La Nga and Xom Moi respectively within a family was full-sibs, and indicated that less than three fathers contributed to pollination of each mother tree. These results suggested that progeny were closely related to each other. Among the outcrossing rates of individual mother trees, high values $\left(t_{m}>0.9\right)$ were found in seven and eight mother trees in La Nga and Xom Moi respectively. Some values were relatively low, found in three mother trees in La Nga and two in Xom Moi. This might be related to their isolation from the rest of the flowering adults. Mother trees for the seed collection were located on the roadside. However, reproductive isolation by differences in their flowering phenology might be considered.

\section{Implications for conservation}

Determination of a mating system of a species shows genetic information from one generation to the next, and is the basis for conservation and breeding programmes (Frankham et al. 2004). Ex-situ conservation activity by seed collection is a key tool to supplement in-situ conservation (Richards et al. 2007). The collected seeds are used as a source of plant material for genetic diversity conservation, restoration and prevention of genetic erosion from random genetic drift and inbreeding effects within natural populations (Frankham 2010). Thus, the ex-situ conservation will increase the species potential to adapt to changing environment in the future
(Bijlsma et al. 1997). Our results indicated that fragmentation from the construction of Tri An artificial lake and clearance of habitat for cultivation did not seriously affect the genetic diversity within Xom Moi and La Nga. These populations still maintained their genetic diversity and are considered as a source for ex-situ conservation. Seeds with different alleles from these populations will be a suitable measure for ex-situ conservation of $D$. dyeri. The seeds from maternal trees with high outcrossing rates will also be selected in ex-situ conservation activities.

\section{ACKNOWLEDGMENT}

The present work was supported by Vietnam National Foundation for Science and Technology Development (project \# 106.06-2017.14).

\section{REFERENCES}

Abasolo MA, Fernando ES, Borromeo TH \& Hautea DM. 2009. Cross-species amplification of Shorea microsatellite DNA markers in Parashorea malaanonan (Dipterocarpaceae). Philippine Journal of Science 138: 23-28.

Anonymous. 2007. Vietnam Red Data Book. Natural Science and Technology Publisher, Hanoi

BARRETT SCH \& KoHN J. 1991. The genetic and evolutionary consequences of small population size in plant: implications for conservation. Pp 3-28 in Falk D \& Holsinger KE (eds) Genetics and Conservation of Rare Plants. Oxford University Press, New York.

BAwA KS. 1998. Conservation of genetic resources in the Dipterocarpaceae. Pp45-55 in Appanah S \& Turnbull JM (eds) A Review of Dipterocarps. Center for International Forestry Research, Bogor.

Bijlsma RJ, Bundgand J, Boerema AC \& Van Putten WF. 1997. Genetic and environmental stress, and the persistence of populations. Pp 193-207 in Bijlsma R \& Loeschcke V (eds) Environmental Stress, Adaption, and Evolution. Birkhanser Verlag, Basel.

Bijlsma R, Van Der Velde M, Van De Zande L, Boerema AC \& VAN Zanten BO. 2000. Molecular markers reveal cryptic species within Polytrichum commune (common hair-cap moss). Plant Biology 2: 408-414. https://doi.org/10.1055/s-2000-5952.

DoYle JJ \& DoYle JL.1990. Isolation of plant DNA from fresh tissue. Pocus 12: 13-15.

Eduardo A, De Lacerda B, Kanashiro M \& Sebbenn AM. 2008. Long-pollen Movement and Deviation of Random Mating in a Low-density Continuous Population of a Tropical Tree Hymenaea courbaril in the Brazilian Amazon. Biotropica 40: 462-470. https://doi. org/10.1111/j.1744-7429.2008.00402.x.

Frankham R. 2010. Challenges and opportunities of genetic approaches to biological conservation. Biological Conservation 143: 1919-1927. doi:10.1016/j. biocon.2010.05.011. 
Frankham RJ, Ballou D \& Briscoe DA. 2004. A Primer of Conservation Genetics. Cambridge University Press, Cambridge.

Fukue Y, Kado T, Lee SL, Ng KKS, Muhammad N \& Tsumara Y. 2007. Effects of flowering tree density on the mating system and gene flow in Shorea leprosula (Dipterocarpaceae) in Peninsular Malaysia. Journal Plant Research 120: 413-420. doi 10.1007/s10265007-0078-z.

Hamrick JL. 2004. Response of forest trees to global environmental changes. Forest Ecology and Management 197: 323-335. doi:10.1016/j.foreco.2004.05.023.

Kitamura K, Rahman AM, Ochiai Y \& Yoshimaru H. 1994. Estimation of the outcrossing rate on Dryobalanops aromatic Gaertn. F. in primary and secondary forest in Brunei, Borneo, Southeast Asia. Plant Species Biology 9: 37-41. https://doi.org/10.1111/j.1442-1984.1994. tb00080.x.

Isagi V, Kenta T \& Nakashizuka T. 2002. Microsatellite loci for a tropical emergent tree, Dipterocarpus tempehes V. S1 (Dipterocarpaceae). Molecular Ecology Notes 2: 12-13. http://dx.doi.org/10.1046/j.14718286.2002.00127.x.

LeE SL, Wickneswari R, MAHANI MC \& Zakit AH. 2000. Mating system parameters in a tropical tree species, Shorea leprosula Miq. (Dipterocarpaceae), from Malaysian lowland dipterocarp forest. Biotropica 32: 693-702. https:/doi.org/10.1111/j.1744-7429.2000.tb00517.x.

Lenormand T. 2002. Gene flow and the limits to natural selection. Trends in Ecology and Evolution 17:183-189. doi: 10.1016/S0169-5347(02)02497-7.

Lowe AJ, Boshier D, Ward M, Bacles CFE \& Navarro C. 2005. Genetic resource impacts of habitat loss and degradation, reconciling empirical evidence and predicted theory for neotropical trees. Heredity 95: 255-273. doi:10.1038/sj.hdy.6800725.

Muhammad AJ, Cannon CH \& Wickneswari R. 2016. Crossspecies amplification of microsatellite DNA markers in Shorea playtyclados. Journal of Forestry Research 27: 27-32. doi:10.1007/s11676-015-0134-9.

MuraWsKI DA \& BAWA KS. 1994. Genetic structure and mating system of Stemonoporus oblongifolius (Dipterocarpaceae) in Sri Lanka. American Journal of Botany 81: 155-160. https://doi. org/10.1002/j.1537-2197.1994.tb15424.x.

Murawski DA, Dayanandan B \& Bawa KS. 1994. Outcrossing rates of two endemic Shorea species from Sri Lankan tropical rain forests. Biotropica 26: 23-29. doi:10.2307/2389107.

NG KSK, LeE SL \& KoH CL. 2004. Spatial structure and genetic diversity of two tropical tree species with contrasting breeding systems and different ploidy levels. Molecular Ecology 13: 1-13. doi:10.1046/j.1365294X.2004.0294.x.

NGHIA NH. 2005. Dipterocarps of Vietnam. Agriculture House, Hanoi.

Nguyen THH, Nguyen MD, Dang PH et al. 2015. Genetic diversity of Dipterocarpus dyeri in the tropical forests of Tan Phu (Dong Nai). Journal of Biology 38: 81-88. doi:10.15625/0866-7160/v38nl.7531.

Obayashi K, Tsumura Y, Ihara-Ujino T et al. 2002. Genetic diversity and outcrossing rate between undisturbed and selectively logged forests of Shorea curtisii
(Dipterocarpaceae) using microsatellite DNA analysis. International Journal Plant Science 163: 151-158. doi 10.1086/324549.

Pandey M \& Geburek T. 2009. Successful cross-amplification of Shorea microsatellites reveals genetic variation in the tropical tree, Shorea robusta Gaertn. Hereditas 146: 29-32. http://dx.doi.org/10.1111/j.16015223.2009.02070.x.

PANDEY M \& GEBUREK T. 2011. Fine genetic structure and gene flow in a semi-isolated population of a tropical tree, Shorea robusta Gaertn. (Dipterocarpaceae). Current Science 101: 293-299.

Phan KL, Newman MF, Khou E et al. 2017. Dipterocarpus dyeri. The IUCN Red List of Threatened Species 2017: e.T33011A2830391. http://dx.doi.org/10.2305/ IUCN.UK.2017-3.RLTS.T33011A2830391.en.

Rachmat HH, Kamiya K \& HaRAda K. 2012. Genetic diversity, population structure and conservation implication of the endemic Sumatran lowland dipterocarp tree species (Shorea javanica. International Journal of Biodiversity Conservation 4: 573-583. doi:10.5897/ IJBC12.045.

Richards CM, Antolin MF, Reilley A, Poole J \& Walters C. 2007. Capturing genetic diversity of wild populations for ex-situ conservation: Texas wild rice (Zizania texana) as a model. Genetic Resources and Crop Evolution 54: 837-848. doi:10.1007/s10722-006-9167-4.

Ritland K. 1989. Correlated mating in the partial selfer Mimulus guttatus. Evolution 43: 848-859. doi:10.1111/j.1558-5646.1989.tb05182.x.

Ritland K \& JAIN S. 1981. A model for the estimation of mating systems using $\mathrm{n}$ independent loci. Heredity 47: 35-52. https://doi.org/10.1038/hdy.1981.57.

Takeuchi Y, Ichikawa S, Konuma Yet al. 2004. Comparison of the fine-scale genetic structure of three dipterocarp species. Heredity 92: 323-328. http://dx.doi. org/10.1038/sj.hdy.6800411.

Tam NM, Duy VD, Duc NM, Giap VD \& Xuan BTT. 2014. Genetic variation in and spatial structure of natural populations of Dipterocarpus alatus (Dipterocarpaceae) determined using single sequence repeat markers. Genetic Molecular Research 13: 5378-5386. http://dx.doi.org/10.4238/2014. July. 24.17

TERAUCHI R. 1994. A polymorphic microsatellite marker from the tropical tree Dryobalanops lanceolata (Dipterocarpaceae). Japan Journal of Genetics. 69: 567-576. http://dx.doi.org/10.1266/jig.69.567.

Trang NTP, Huong TT, Duc NM, Tim S \& Triest L. 2014. Genetic population of threatened Hopea odorata Roxb. in the protected areas of Vietnam. Journal of Viet Environment 6: 69-76. doi:10.13141/jve.

Villagra PE, Defosse GE, Del Vslle HF et al. 2009. Land use and disturbance effects on the dynamics of natural ecosystems of the Monte Desert: implications for their management. Journal of Arid Environments 73: 202-211. doi:10.1016/j.jaridenv.2008.08.002.

Ujino T, Kawahara T, Tsumara Y, Nagamitsu T, Yoshimaru H \& Ratnam W. 1998. Development and polymorphism of simple sequence repeat DNA markers for Shorea curtisii and other Dipterocarpaceae species. Heredity 81: 422-428. http://dx.doi.org/10.1046/j.13652540.1998.00423.x. 
